\title{
DEVELOPMENT MODEL APPROACH THROUGH EXERCISE KINESTHETIC GAME CIRCUIT FOR CHILDREN AGES 4-6 YEARS
}

\author{
Bangkit Seandi Taroreh \\ bangkitseanditaroreh@gmail.com \\ Universitas Budi Darma Palembang
}

\begin{abstract}
This study aims to develop a basic kinesthetic based motion activity model for children aged 4-6 years. The design of this study refers to the Borg and Gall development model consisting of ten steps. These steps are 1) preliminary study aims to know the needs analysis in developing physical activity. It was concluded that a basic kinesthetic based motion activity model is required for children aged 4-6 years, 2) planning by formulating forms of participation in research); 3) design development, done by drafting and validated to 4 (four) experts and 1 (one) practitioner with 52 basic motion based kinesthetic activities, 4) conducting limited field test using 20 subjects, 5) revision of field test result limited clarity of implementation procedure and handbook, 6) broader field test using 50 subjects, 7) the revision of the field test results is broader, nothing needs to be revised because all aspects already meet the standards, 8) the main test through the model effectiveness test done 40 subjects, 9) the final product, 10) dissemination. Subjects in this study were children aged 4-6 years in Kindergarten. Place of research conducted in Tangerang City. Data were collected through documentation, observation, questionnaires and kinesthetic tests. Data analysis is done descriptively from qualitative and quantitative data. The results of the study are the basic kinesthetic based motion activity activity for children aged 4-6 years. The results prove that the development of a kinesthetic based motion activity model for children aged 4-6 years has been declared valid by motor learning experts, physical activity experts and early childhood education practitioners.
\end{abstract}

Keywords: basic motion activity, kinesthetic, children aged 4-6 years.

As the development of the sports age not only progressed to the achievement of peak performance but also developed in the education path. It is in accordance with the National Sports System that the scope of sport includes activities 1) sports education, 2) recreational sports, and 3) sports achievements (Kemenpora, 2014:10). The development of sports education, recreational sports and sports achievements will be related to each other.

Sports culture is built from the process of sports pemassalan on the community, including through various aktiviftas sports education and sports club early age. This becomes part of the foundation to find potential athlete seeds to achieve the peak of Indonesia's sports achievements. The National Sports System describes sports education organized as part of the educational process. Sports education begins at an early age (Kemenpora, 2014:10). Therefore it is very important role of sports education at an early age. This paradigm brings influence on the field of education, especially the implementation of early childhood education, so the view that education is an integral part of the overall system of early childhood education.

Over time gradually the government's attention began to focus on education before the level of basic education ie early childhood education. The large potential of Indonesia's population with the number of children aged 3-6 years in 2015 reached 19,113,800 people (Kemdikbud, 2014:1). This is a matter of consideration of the Government that the need for proper education handling for early childhood can continue the history of life of the Indonesian nation.

Education in kindergarten is a formal education organized as an effort to help lay the groundwork of development on all aspects before entering school. Early age is a sensitive age to receive stimuli and is crucial for the development of children in the future. The Regulation of the Minister of National Education explains that early childhood education is a guidance addressed to children from birth up to the age of six that is implemented through the provision of educational stimuli to foster physical and spiritual 
growth and development in order for the child to have readiness in entering further education. Many efforts made by teachers and parents in helping the growth and development of physical and spiritual one of them through the provision of various physical activities.

The development of educational sports through various physical activities for early childhood is given as one stimulus to help physical and spiritual growth and development. Physical activity is a term used to describe the movement of the human body as a result of skeletal muscle work (Nani Cahyani Sudarsono, 2015:70-76). Physical activity can be done indoors or in an open environment (field area) school. In detail Paiman (2009:270-280) explains that the development of physical activity and sports for early childhood have characteristics that are 1) to provide multilateral training in the form of game and race, 2) to stimulate the development of all five senses, 3) develop imagination / fantasy, and 4) move to the rhythm / song or story. Further explained that physical activity and sports for early childhood is packed in the form of a game or race so that children feel attracted and get pleasure.

The development of various physical activities at school has been applied abroad. It is also revealed by James Tangkudung (2012:8) that the State in the Eastern Europe region develops basic skills training programs such as running, jumping, throwing, catching, rolling, and maintaining balance through multilateral development in schools. The training program has been designed based on the concept of long-term athlete development (LTAD) development based on growth characteristics and child development. Istvan Balyi (2013:2) reveals long-term athlete development is a new approach by giving children the opportunity to be actively involved in lifelong sporting activities and improve health quality if children have greater talent and encouragement will have the chance to become a potential athlete.

Conditions in Indonesia, the concept of long-term athlete development (LTAD) development in accordance with the characteristics of Indonesian society type has not been fully developed in every sport although Indonesia has the potential to achieve optimal sports performance because Indonesia has a large population. Need to elaborate more detail from concept of building of sports system by reformulating addition of program at every stage of chronological age and age of training so that will be composed of role model of long term athlete development (LTAD) according to characteristic of society type of Indonesia. Suppose that has been composed is LTAD weight lifting Indonesia and LTAD badminton sports Indonesia, it is necessary to follow other sports.

Istvan Balyi (2013:10) describes the 4-6 year age phases including the active start stage, the first stage of the seven stages of long-term athlete development (LTAD) development. An important aspect of the active start phase is learning basic motion skills, playing by combining different gestures, improving the development of brain function, coordination, social skills, rough motor skills, emotions, and imagination (Istvan Balyi, 2013:187). The theory is then developed by raising a variety of mutually supportive opinions. Sergio Lara (2005:4) reveals the 4-6 years age phase of developing good physical activity habits with comfort driven from within, David L. Gallahue and John C. Ozmun (2002:46) describes the age of 4-6 years into the basic phase of motion. While Mukhtar Latif (2013:10) argues that in its development from birth to enter basic education is a golden period as well as a critical period in the human stage, which will determine the development of the next child. These periods are a great time to lay the foundations of physical, linguistic, social, emotional development, self-concept, art, morals and religious values. In conclusion, the Ministry of National Education (2007:5) has developed a guideline for the development of physical/motor development, which explains that the development of physical ability in early childhood includes strength development, endurance, agility, flexibility, accuracy and balance.

Children who tend to have low physical activity will usually have an impact on motor skills, so it can be said children with low physical activity ability will result in motor skills that tend to be low too. This will have an impact on the weakness of the child's ability when faced with the physical ability of the motor so that not infrequently found children with weak motor skills, minimal in social interaction with peers. On the other hand children who have good physical motor skills they will have a high confidence.

Permendiknas number 58 year 2009 mention kindergarten services (TK) with characteristics of chronological age 4-6 years has a level of motor development achievement in motor skills coarse and fine motor. The level of developmental achievement describes the growth and development that the child is expected to reach in that age range. Rough motorcycles are the largest areas of early age development 
including the ability to crawl, crawl, stand, walk, run, jump, throw, catch, climb, kick and slide. The development of fine motor increases the coordination of gestures involving muscle groups and other small nerves. For example in terms of writing, his writings will be too pressing so that his writing through the paper or between letters rarely (distance). In addition, when children jump, it requires a good balance, good coordination skills and motor planning (good motion planning). When you want to jump over the rope, he should have a plan whether he will land on one leg or two feet. Then if using one leg, which leg will be used. If the child is not strong in the development of a jump, it will usually face difficulties in an organized plan and task (tasks that require motor planning skills).

The ability of motor planning is also influenced by kinesthetic ability. Kinesthetic is the sense of movement due to muscle stimulation that acts as a feedback mechanism that gives the individual an awareness of the body's position in controlling the movement more precisely. Richard A. Magill (2011:89) describes feedback is information from the sensory system that shows the status of motion to the central nervous system, used to make ongoing movement correction. Ellis Cashmore (2002:111) argues that feedback is part of the skills acquisition mechanism. Kinesthetic will perform its function through perceptual mechanism. Furthermore, the perceptual mechanism will relate to the processing of information within the child. The sharpness of kinesthetic perception will give greater possibilities in making adjustments of his position and body movements to the correctness of the motion task performed.

The process of a movement starts from the presence of external or internal signals that enter through the brain nerve which then causes the contraction of a muscle or muscle group. Rusli Lutan (2013:56) states that the contraction generates sensory information (response-produced feedback) from the muscles and / or from the movements produced by the contracting muscles.

Feedback is considered as a stimulus of information that then serves as a triger or spur for the next contraction. In the next stage, the muscle contraction also produces a feedback response that spurs the third contraction, and so on until a complete contraction circuit takes place. Cheryl A Coker (2004:22) simply about processing information can be seen in the following picture:

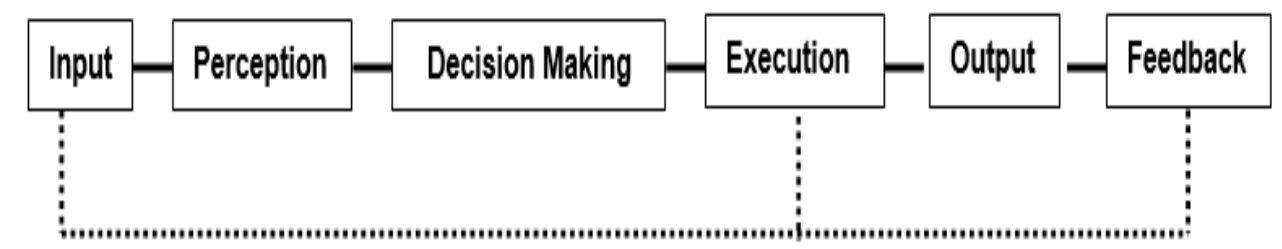

Figure 1. Information Processing Model

(Source: Cheryl A Coker, Motor Learning and Control for Practitioners (New York: Mc Graw Hill, 2004), p.22)

Sources of information that pass through our hearing or sight, are processed in the brain by recognizing and identifying the characteristics of the stimulated input. Then our body will respond well in the form of a movement.

Increased kinesthetic ability will affect the information processing system of motion which will become the embryo of kinesthetic intelligence is ultimately useful for the life of children in the future. The degree of kinesthetic sensitivity is determined by motor skills and almost everyone has different levels of kinesthetic sensitivity. William H Edward (2011:77-78) describes the maximum kinesthetic sensitivity of a person reaching a peak at the age of 12 years but if there is a gradual decrease in kinesthetic sensitivity in the next year it does not pose a real problem to the performance of daily skills by always maintaining an active lifestyle 
A key component of learning about kinesthetic is through exercise (Andrew P. Winterstein, 2003:60). Physical activity through play is given in Kindergarten with characteristics of 4-6 years of age as a form of experience of basic movements in the school. The purpose of playing by creating as much physical activity as possible in order to control the brain connections so that the brain learn to control various types of movement that will be useful in the future (Istvan Balyi, 2013:10). Basic kinesthetic based motion activity is the sense of movement of body position, orientation of space and balance of the body as a source of feedback information to the central nervous system through a series of basic motion.

Preliminary study conducted by researchers by collecting data through document studies, observations, and questionnaires. The results of document studies derived from rough participation rate / net enrollment rate Year 2014/2015 obtained data among others:

1) Number of children aged 3-6 years in 2015 in Banten Province of 948,330 children. This suggests that so large the number of children of early age so that require appropriate early education services.

2) Rural Participation Rate (APK) of PAUD in 2015 Banten Province is ranked 28 out of 34 provinces in Indonesia with a percentage of $54.71 \%$ or 518,834 children. The low ranking of Banten Province shows the low acceptance of parents to the implementation of early childhood education.

3) Rural Participation Rate (APK) of PAUD in 2015 Banten Province is ranked 6 (six) from all provinces in Java Island.

Table 1. Comparison of APK PAUD in 2015 Banten Province with All Provinces in Java Island

\begin{tabular}{|c|l|l|c|}
\hline No. & \multicolumn{1}{|c|}{ Province } & \multicolumn{1}{|c|}{ Rough Participation Rate } & Percentage \\
\hline 1 & D.I Yogyakarta & 212.257 of 213.720 children & $99,32 \%$ \\
\hline 2 & Jawa Timur & 2.207 .697 of 213.720 children & $91,53 \%$ \\
\hline 3 & Jawa Tengah & 1.586 .998 of 2.229 .940 children & $71,17 \%$ \\
\hline 4 & Jawa Barat & 2.184 .611 of 3.407 .790 children & $64,11 \%$ \\
\hline 5 & DKI Jakarta & 438.716 of 729.300 children & $60,16 \%$ \\
\hline 6 & Banten & 518.834 of 948.330 children & $54,71 \%$ \\
\hline
\end{tabular}

4) Tangerang City is in position 5 of 8 districts in Prov. Banten with a percentage of $56.38 \%$ from 155,464 children. This shows that parents' acceptance of PAUD administration in Tangerang City is still low among all districts in Prov. Banten.

Based on data of study result of document study give an illustration that the low of parent's acceptance to the implementation of early childhood education, this is the reason why researcher do research in Tangerang City, Banten Province.

The result of observation obtained the data of motor learning implementation as follows:

Table 2. Allocation of Motorized Learning Time in Kindergarten

\begin{tabular}{|c|c|c|c|c|c|c|}
\hline \multirow{2}{*}{$\begin{array}{c}\text { Implementation } \\
\text { of motor } \\
\text { learning }\end{array}$} & \multicolumn{2}{|c|}{ Per week } & \multicolumn{2}{c|}{ Per semester } & \multicolumn{2}{c|}{ Per year } \\
\cline { 2 - 7 } & $\begin{array}{c}\text { Amount } \\
\text { meeting }\end{array}$ & $\begin{array}{c}\text { Total } \\
\text { Duration }\end{array}$ & $\begin{array}{c}\text { Amount } \\
\text { meeting }\end{array}$ & $\begin{array}{c}\text { Total } \\
\text { Duration }\end{array}$ & $\begin{array}{c}\text { Amount } \\
\text { meeting }\end{array}$ & $\begin{array}{c}\text { Total } \\
\text { Duration }\end{array}$ \\
\cline { 2 - 7 } & $2 \mathrm{x}$ & $\begin{array}{c}60 \\
\text { minutes }\end{array}$ & $34 \mathrm{x}$ & $\begin{array}{c}1020 \\
\text { minutes }\end{array}$ & $68 \mathrm{x}$ & $\begin{array}{c}2040 \\
\text { minutes }\end{array}$ \\
\hline
\end{tabular}

Based on these data can be analyzed that the duration of time on motor learning conducted in kindergarten provides great opportunities for children to learn basic motion and enjoy the activity actively. Things that need to be considered and prepared by the teacher is to create an environment in the form of various physical activities that stimulate the child to be physically active so that fulfilled the physical needs of the child every day. The requirement of physical activity of children at least 60 minutes 
every day with several periods of active short play so that its implementation should not continue but must be separated.

To deepen the data that has been obtained then the researchers spread the questionnaires to 17 teachers in Tangerang City. The results obtained by the data as follows:

1) Kindergarten in Tangerang City provides physical development services through sports activities and motor learning, $100 \%$ (17 teachers) disclose it.

2) The weakness of motor learning, among others, is because 1) the lack of teachers especially those who have a scientific background of physical education because the average is a graduate of high school and S1, 2) the lack of space (field) around the school, 3) 4) less cost, 5) sometimes visible children less excited, bored, 6) still limited the basic kinesthetic based motion physical activity model for children aged 4-6 years.

3) The forms of physical activity in motor lessons are often done include: 1) gymnastics, 2) play slide, 3) around the school environment, 4) puzzle play, 5) creep and jump over hoops, 6) play ball, 7) Coloring, 8) recreational activities, 9) cat and mouse game, 10) rubber relay, 11) making APE, 12) playing blocks, 13) cycling, 14) swimming, 15) playing seesaw, 16) outdoor games.

4) It takes the development of other physical activity one of which is the development of kinesthetic based motion based activity model for children aged 4-6 years. This is $100 \%$ (17 teachers) agreed.

Various physical activity analyzes for children aged 4-6 years have been disclosed above. The matrix structure of the old physical activity model with the model to be developed as follows:

\section{Table 3. Physical Activity Model Structure Matrix}

\begin{tabular}{|c|c|c|}
\hline No. & Old Physical Activity & Physical Activity Developed \\
\hline 1 & Uncollected activity & $\begin{array}{l}\text { Patterned activity is performing a series of } \\
\text { physical activities including locomotor motion, } \\
\text { non locomotor and kinesthetic based manipulative }\end{array}$ \\
\hline 2 & $\begin{array}{l}\text { The development of physical } \\
\text { activity is less interesting }\end{array}$ & $\begin{array}{l}\text { The activity of the child is interesting by } \\
\text { considering the specific aspects of responding, } \\
\text { motor chaining, rule using even in a simple way. }\end{array}$ \\
\hline 3 & $\begin{array}{l}\text { Existing forms of physical } \\
\text { activity make some children } \\
\text { less enthusiastic }\end{array}$ & $\begin{array}{l}\text { Children are more happy, enthusiastic and active } \\
\text { so as to cultivate the participation of all children }\end{array}$ \\
\hline 4 & $\begin{array}{l}\text { There has been no clear } \\
\text { reinforcement of the success } \\
\text { of any child activity }\end{array}$ & $\begin{array}{l}\text { The existence of the strengthening of the success } \\
\text { of the child in the form of successful experience } \\
\text { of successful completion of various basic } \\
\text { movement activities. }\end{array}$ \\
\hline 5 & $\begin{array}{l}\text { Physical activity is } \\
\text { constrained in the absence of } \\
\text { extensive land around the } \\
\text { school and the existence of } \\
\text { limited tools }\end{array}$ & $\begin{array}{l}\text { Using simple equipment so as to overcome the } \\
\text { limitations of the tool. }\end{array}$ \\
\hline
\end{tabular}

Based on the results of needs analysis (need assessment), this research will develop a model of kinesthetic based motion based activities for children aged 4-6 years.

\section{METHOD}

The design of this study researchers refer to Borg and Gall development research model. Steps include: 1) preliminary study, 2) planning, 3) design development, 4) conducting a limited field test using 20 subjects, 5) revision of limited field test results, 6) broader field testing using 50 subjects , 7) revision 
of field test results more widely, 8) main test through model effectiveness test done 40 subjects, 9) final product, 10) dissemination.

The subjects of this study are children aged 4-6 years who are students of kindergarten. The type of data produced in the form of quantitative data and qualitative data. Data were collected through documentation, obsevation, questionnaires and kinesthetic tests. Data analysis was done descriptively, from qualitative and quantitative data. The qualitative data is derived from the results data from expert suggestions and inputs. Quantitative data use descriptive quantitative analysis technique with percentage and statistic Test-T on product effectiveness test.

\section{RESULT}

The results of this development study resulted in a book product of kinesthetic based motion activity for children aged 4-6 years containing 52 forms of physical aktvitas consisting of various variations of non locomotor motion (17 forms of activity), locomotor (16 forms of activity), manipulative (19 forms activity). Basic motion activity is developed according to three factors: 1) conscious body position, 2) orientation of space, and 3) balance. The results of model effectiveness test in 40 children showed the following results:

\section{Tabel 4.}

Paired Samples Statistics Pretest dan Posttest

\begin{tabular}{|rl|r|r|r|c|}
\hline & & Mean & N & Std. Deviation & $\begin{array}{c}\text { Std. Error } \\
\text { Mean }\end{array}$ \\
\hline Pair 1 & Pretest & 9.4250 & 40 & 6.76676 & 1.06992 \\
& Postest & 6.5750 & 40 & 5.25204 & .83042 \\
\hline
\end{tabular}

Based on the above table that the average value of kinesthetic test results before the basic kinestheticbased motion activity model is $9.4250 \mathrm{~cm}$ and after treatment is $6.5750 \mathrm{~cm}$. The test results show the jump result is closer to the predetermined target so that the kinesthetic ability of the child increases.

\section{Tabel 5. Paired Samples Correlation Pre Test dan Post Tes Paired Samples Correlations}

\begin{tabular}{|ll|c|c|c|}
\hline & & $\mathrm{N}$ & Correlation & Sig. \\
\hline Pair 1 & Pretest \& Postest & 40 & .727 & .000 \\
\hline
\end{tabular}

Based on the output table above that the correlation coefficient before and after given the model with $\mathrm{p}$ value $0.00<0.05$ so the conclusion there is a significant relationship.

Tabel 6. Paired Samples Test Pre Test dan Post Tes

Paired Samples Test

\begin{tabular}{|c|c|c|c|c|c|c|c|c|}
\hline & \multicolumn{5}{|c|}{ Paired Differences } & \multirow[b]{3}{*}{$\mathrm{t}$} & \multirow[b]{3}{*}{$\mathrm{df}$} & \multirow{3}{*}{$\begin{array}{l}\text { Sig. (2- } \\
\text { tailed) }\end{array}$} \\
\hline & \multirow[b]{2}{*}{ Mean } & \multirow{2}{*}{$\begin{array}{c}\text { Std. } \\
\text { Deviatio } \\
\mathrm{n}\end{array}$} & \multirow{2}{*}{$\begin{array}{c}\text { Std. Error } \\
\text { Mean }\end{array}$} & \multicolumn{2}{|c|}{$\begin{array}{l}\text { 95\% Confidence } \\
\text { Interval of the } \\
\text { Difference }\end{array}$} & & & \\
\hline & & & & Lower & Upper & & & \\
\hline $\begin{array}{ll}\text { Pair } & \text { Pretest - } \\
1 & \text { Postest }\end{array}$ & $\begin{array}{r}2.850 \\
00\end{array}$ & 4.65502 & .73602 & 1.36125 & 4.33875 & 3.872 & 39 & .000 \\
\hline
\end{tabular}


In the significance test of difference using SPSS obtained Mean $=2.85000$ shows the difference of pretest and posttest, $\mathrm{t}$-hitung $=3.872 \mathrm{df}=39$ and $\mathrm{p}$-value $=0.00<0.05$ which means there is a significant difference between before and after the model treatment.

\section{CONCLUSION}

Based on the results of this study it can be concluded that the kinesthetic based motion based activity model for children aged 4-6 years developed has significant effectiveness so that it can be used and applied for for children aged 4-6 years. This study can be concluded that has produced a book product in the form of kinesthetic based motion based activity model for children aged 4-6 years.

\section{REFERENCES}

Andrew P. Winterstein, Athletic Training Student Primer a Foundation for Success. USA: SLACK Incorporated, 2003.

Cheryl A Coker, Motor Learning and Control for Practitioners. New York: Mc Graw Hill, 2004.

David L Gallahue dan John C. Ozmun, Understanding Motor Development Infants, Childrens, Adolescents, Adults Fifth Edition. New York: Mc Graw Hill, 2002.

Depdiknas, Pedoman Pembelajaran Bidang Pengembangan Fisik/Motorik Di Taman Kanak-Kanak. Jakarta, 2007.

Ellis Cashmore, Sport Psychology. USA: Routledge, 2002.

Istvan Balyi, Richard Way, dan Colin Higgs, Long-Term Athlete Development. United States Of America: Human Kinetics, 2013.

James Tangkudung dan Wahyuningtyas Puspitorini, Pelatihan Olahraga Pembinaan Prestasi Olahraga Edisi II. Jakarta: Cerdas Java, 2012.

Kemenpora, Undang-Undang Nomor 3 Tahun 2005 Sistem Keolahragaan Nasional. Jakarta: Kemenpora, 2014.

Mukhtar Latif dkk, Orientasi Pendidikan Anak Usia Dini. Jakarta: Kencana Prenada Media Group, 2013.

Nani Cahyani Sudarsono, "Indikator Keberhasilan Pengelolaan Aktivitas Fisik pada Penyandang Diabetes Militus Tipe 2," eJurnal Kedokteran Indonesia, Vol. 3 (1), April 2015.

Paiman, Olahraga dan Kebugaran Jasmani pada Anak Usia Dini. Yogyakarta: Cakrawala Pendidikan, 2009.

Permendiknas Nomor 58 Tahun 2009.

Richard A. Magill, Motor Learning and Control Conceps and Applications Ninth Edition. New York: Mc Graw Hill, 2011.

Rusli Lutan, Pedoman Perencanaan Pembinaan Olahraga. Jakarta: Asdep Iptekor Kemenpora, 2013.

Sergio Lara, Coaching for Long-term Athlete Development: Improving children's participation and performance in sport. New York: Coachwise Limited, 2005.

William H Edward, Motor Learning and Control From Theory to Practice. USA: Wadsworth Cengage Learning, 2011. 